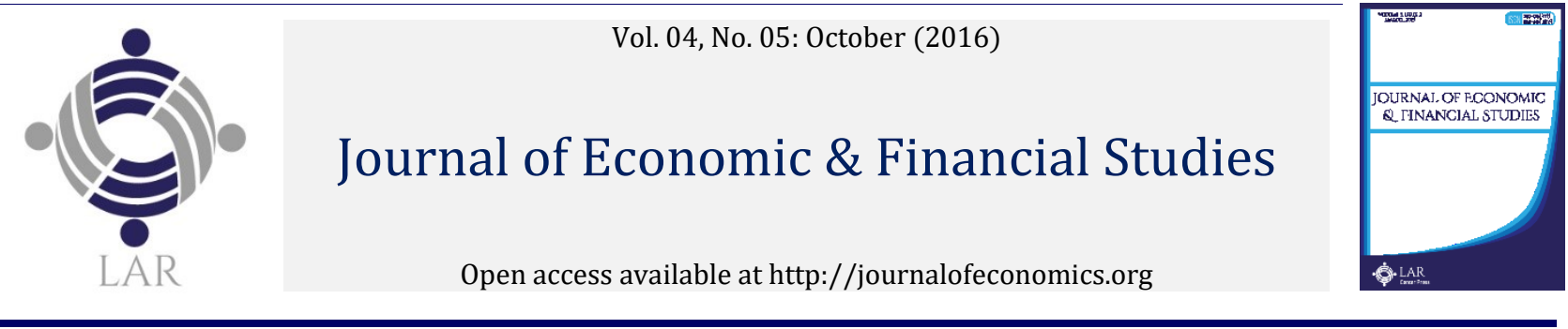

\title{
Chinese born global firms and international entrepreneurial mechanism $^{\times}$
}

\author{
Junjie Zhang ab*, Rongyao Cheng a, Weibin Wang b \\ a Xuri Business School, Donghua University, 200051, Shanghai, China. \\ b Business School, Jiaxing University, Jiaxing 314001, China. \\ *Corresponding author's email address: junjiezhanguk@163.com
}

\author{
A R T I C L E I N F O \\ Received: 23-09-2016 \\ Accepted: 16-11-2016 \\ Available online: 21-10-2016 \\ Keywords: \\ Global firms; \\ International entrepreneurship; \\ Overseas market opportunity.
}

\begin{abstract}
A B S T R A C T
This paper explores Chinese-born global firms' entrepreneurial mechanism and development mode from multi-theoretical perspectives using company case studies. The findings suggest that for Chinese born global firms, overseas market opportunity's recognition and exploitation is the starting point and catalyst for their establishment and growth, while global resources integration is growing mode for their continuous development. Results suggest that overseas market knowledge and organization learning are the bases for Chinese born global firms to cultivate and maintain sustainable competitive advantages after they have entered international markets.
\end{abstract}

JEL Classification: F12, F14, L26.

(C) 2016 The Authors. This is an open access article under the terms of the Creative Commons Attribution License 4.0, which allows use, distribution, and reproduction in any medium provided the original work be properly cited.

\subsection{Introduction}

China's growing international integration into the world economy and its outward foreign direct investment especially in astounding cross-border M\&A activities such as TCL's acquisition of French Thomson in 2003, Lenovo's acquisition of IBM PC business unit in 2005 and Geely a obscure Chinese private-owned automobile company's acquisition of world famous car brand Volvo in 2010 have attracted many international business scholars' great attention, while beneath that high-visibility media coverage about M\&A activities undertaken by Chinese giant corporations with long histories, a large number of Chinese small and medium enterprises have also emerged to embark on international expansion journey, some even targeted international markets as a primary source of sales from their inception or very shortly after company's foundation, which are termed as "Born Global or International new venture" in academic field which belong to cross discipline of international business and entrepreneurship research put forwarded by Oviatt and McDougall in their milestone paper named toward theories of international new ventures. (Oviatt and McDougall, 1994)

In that paper, they have used two companies in United States (LASA Industries, Inc and IXI Limited) as case studies to indicate that new venture's internationalization phenomenon which was neglected in past research. They described: "LASA Industries, Inc., which sold an unusually efficient microprocessor prototyping technology, is representative of these international new ventures formed within the past decade. Its founders were American, Swiss and French. Its funding was European. The operational headquarters and R\&D were in the United States,

\footnotetext{
${ }^{x}$ The paper is co-supported by Zhejiang provincial soft science project (2016C25012) and grants of philosophy and social sciences planning projects of Zhejiang province (17NDJC093YB) and (13NDJC052YB).
} 
while marketing was managed from France and finance from Switzerland. Manufacturing was centered in Scotland, and initial sales were in France and the United States". "IXI Limited, a British venture that became a leading supplier of desktop windowing computer software for UNIX operating systems, violated the usual expectation that firms begin with sales in their home country and later sell to foreign countries. When Anderson (a British company founder) started IXI, his strategy was to target the United States first, Japan second, and then move back into the United Kingdom." (Oviatt and McDougall, 1994).

Although lots of research on this new breed of enterprises can be found in extant literature, most of them are conducted under western developed countries' context. The paper tries to assess the validity of western born global theories by applying them to Chinese context since in practice; there is also a large amount of small and medium Chinese firms internationalize very rapidly at the inception or very shortly after company's foundation. For example, Chinese ZhanXun Telecommunication Company specializing in wireless telecommunication and multi-media end core CPU, customized software and reference design platform's development was founded in the year 2001. From its initial inception, company's founding team immediately took advantages of global talents, favored governmental policies and technological superiority in different locations of the world to boost ZhanXun Company's internationalization development. The company has set up R\&D centers and subsidiaries in Silicon Valley, Austin, and Chinese Taibei. In 2007, the company was listed on NASDAQ stock exchange, in 2008, ZhanXun Company acquired American Quorum Company to further its international expansion. Another Chinese case company was Sun-Tec Corporation which is specialized in solar energy generating products manufacturing and research. In 2001, the company's founder Dr. Zhengrong Shi returned China to set up Sun-Tech Corporation with his accumulated rich knowledge and experiences in photovoltaic industry studied in Australia. At the beginning of company's development, Sun-Tech succeeds in expanding into the European market by focusing on German market rather than following gradual domestic market to overseas market process. Currently, Sun-Tech takes important sales percentage in European and North American, Middle Eastern, and South eastern Asian market, while single European market has occupied $90 \%$ of sales in Sun-Tech Corporation.

Therefore, two intertwined and step-up questions should be seriously taken account into: How can Chinese born-global firms involve international activities in their early stages? How do Chinese born-global firms utilize global resources they can access to evolve and compete with formidable established MNCs?

Traditional international business theories reckoned that enterprises tend to expand into international markets after they have gradually developed well in domestic markets. Among traditional theories, Johanson and Vahlne (1977)'s Uppsala mode seems the most persuasive one. However, as economic globalization and information technologies' fast development; the global business environment has undergone fundamental changes. Since the 1990s, lots of small firms had successfully implemented international expansion just after firms' foundation or in a very short period of inception; those firms are featured with clear globalization mindset at the beginning, innovative, customized, flexible technology and product design which can rapidly make an adjustment to meet niche customer needs. (Madsen, Servais, 1997) That phenomenon is not constrained to only some western developed countries but is also widely existed in other parts of the world such as Middle East, Asia, and South Pacific regions. In China, as the pace of firms' internationalization quickens, a bundle of high-technology firms targeted international markets when they were just established, and they have successfully realized a high degree of internationalization of capital, technology, human resources and markets in a very short time. Although those firms are very small, they have successfully survived and competed in international markets, and they also constitute important drivers for China's industry structure upgrading and innovative country's construction, and they are also playing increasingly important role in realizing mass entrepreneurship and innovation strategy advocated by the Chinese government in 2014 .

The paper tries to explore Chinese-born global firms' international entrepreneurial mechanism and development modes through several representative case studies analyses.

\subsection{Characteristics and motives of born global companies}

\subsection{Definition of born global company}

In 1994, Oviatt and McDougall published their seminal paper named toward theories of international new ventures, that paper is widely cited by researchers in the field, they defined international new venture as "a business organization that, from inception, seeks to derive significant competitive advantage from the use of resources and the sale of outputs in multiple countries" (Oviatt and McDougall, 1994). In the paper, the authors also classify those firms into export/import start-up, multinational trader, geographically focused start-up, and global start-up types. Then Knight and Madsen \& Servais reckoned that born global is "firms less than 20 years old that internationalized on average within three years of founding and generate at least 25 percent of total sales from abroad." (Knight, Madsen \& Servais, 2004). Loustarinen \& Gabrielsson (2006) defined global ventures as the 
firms that "have usually first started to internationalize their operations and, on top of that, have entered global markets, deriving most of their income (over 50\%) from non-domestic continents." (Luostarinen \& Gabrielsson, 2006)

\subsection{Some distinctive features of born global firms}

Lots of scholars have summarized distinctive features of born global firms, they believe that majority of born global firms are highly technology oriented, lots of cases from western countries support that born global firms are always firms that own some specific leading edge technology, some of them originate from universities' technical departments and incubators, they are the outcomes of some technological inventions being transferred into commercial usage.

Studies in the field also indicate that more born global firms engage in B2B markets (Business to Business) than in B2C markets (Business to Customer), since number of customers in B2B markets are much smaller than B2C markets, which make it easier for born global firms to serve their business customers with relatively lower cost of marketing and distribution.

Born global firms tend to focus on niche markets rather than commodity markets, due to their limitations in resources and capabilities, it is impossible for them to serve a wide range of customers in industries, some specific kind of customers with specific needs seem more viable for them. Gassmann \& Keupp even proposed "the extent, to which the firm can take a specialized position in international value chains, to be one of the factors that enable an early and rapid internationalization of SMEs" (Gassmann \& Keupp, 2007).

Mort \& Weerawardena (2006), Freeman et al. (2006), Bell et al. (2003) deemed that networking is playing very important role in born global firms' survival and growth in international markets. As mentioned above, born global firms are constrained by resources and capabilities' limitation, thus, networking become viable channels for born global firms to integrate and leverage resources and capabilities externally, they use "vertical and horizontal network relations to rapidly gain access to international markets, to the partners' marketing infrastructure and capabilities" (Coviello \& Munro, 1995), and "to overcome resource limitations related to product development" (Coviello \& Munro, 1997).

Autio believed that absent of embedded organizational routines is the source of born global firms' competitive advantages over some long-established big companies. (Autio et al., 2000) Embedded organization routines sometimes play negative roles in renewing companies' old structure and obsolete business model, thanks to deficiency of those embedded organization routines, born global firms can cultivate innovative and entrepreneurial corporate culture faced with fewer impediments than long-established companies, which is crucial for firms' accelerated internationalization.

Thus, born global firms are featured with inherent entrepreneurial and innovative elements from the beginning, Knight \& Cavusgil argued "international entrepreneurial orientation reflects the firm's overall innovativeness and proactiveness in the pursuit of international markets. It is associated with innovativeness, managerial vision, and proactive competitive posture. A posture that is innovative, visionary, and proactive may be necessary amongst a class of firms that, in the face of relatively limited resources, takes the initiative to pursue new opportunities in complex markets, typically fraught with uncertainty and risk." (Knight, Madsen \& Servais, 2004)

The researchers have not only explored the features of born global firms as complete organization, they have also shed their research attention on the characteristics of born global firms founders, they state that most of the founders have strong entrepreneurial drive, international mindset, and good networking capabilities, some of them also have high level of education, experiences of working for international business in MNCs.

\subsection{Motives of born-global firms}

A very important question must be asked is that why born global firms can embark on internationalization journey in the strikingly short period after inception although they do not own substantial resources and advantages comparing with long-established MNCs. According to prior research, the motives behind can be probed into from three perspectives.

\subsubsection{Entrepreneur is individual perspective}

The entrepreneur's individual perspective attempts to seek the forming and growth factors of born global firms from individual entrepreneur aspect, they stressed entrepreneur's overseas experience and knowledge, international aptitude and categories' influences on the growth of born global firms. Oviatt and McDougall analyzed the different characteristics between born global firms and domestic new firms in the foundation, they 
found that entrepreneur's global mindset and overseas experience are key driving forces to determine the international entrepreneurship. Harveston et al. deemed that managers of born global firms are featured with higher global orientation, risk tolerance and richer international experience comparing with managers in traditional firms which tend to follow gradual stage mode in international expansion.

\subsubsection{Enterprise-level perspective}

Enterprise-level perspective analyzes the born global firms' distinctive features which differentiate from other enterprises. Autio, et al.'s research indicate that most of the born global firms are knowledge-intensive firms because knowledge intensity has amplifying effects on internationalization: in new environment, firms which rely on knowledge's creation and exploitation to cultivate competitive advantages are doing better in adaptive learning than firms which are mainly dependent on physical resources; knowledge, especially explicit knowledge is transferable resource, knowledge's internal fluidity enable it to combine with firms' fixed costs such as manufacturing resources and distribution channels at lower cost. Thus, knowledgeable new ventures are more flexibly in taking advantages of international markets opportunities than firms dependent on physical resources. Knight and Cavusgil (1996) have paid more attention to the innovative culture of born global firms; they considered that born global firms are more international market-oriented in strategy; they focus on developing capabilities needed for internationalization from inception.

\subsubsection{External environment perspective}

Research in that perspective boils down to the emergence and growth of born global firms into the changes of external environment. Madsen and Servais (1997) thought that comparing with countries endowed with large domestic markets, countries with narrow domestic markets will push new ventures to actively expand into overseas markets. McDougall and Oviatt (1994) pointed out that international trade's liberalization, technology advancement of IT, especially the advent of the internet make firms more viable to connect with customers, distributors, and suppliers worldwide, which become the catalyst of born global firms. Other scholars sum the born global firms' Advent up to the results of multi-factors' combination effects: the function of a niche market; development of processing and communication technology; inherent advantages such as flexibility of SMEs; availability of international tools and formation of global networks.

\subsection{Chinese-born global companies case studies}

Since China's open door policy are still relatively short in time comparing with Western developed countries, the quantity of Chinese-born global firms may be smaller than their counterparts, which determine that large quantity research approach may be not very viable due to its requirement for a large amount of research samples. Thus, the paper selects case studies as a research approach, which is in accord with most research approaches in the field. Because the research aim of case studies is to induce relevant theory rather than frequency calculation, so the selection of case studies does not need to follow sampling rule but ensure case studies are special and typical enough. Of course, under the correct circumstances, multiple case studies approach will be more effective to extract theories and form a better structure for research.

\subsection{Individual case study}

The paper selects three Chinese new established small and medium firms with international sales as case studies. The reasons for choosing those three companies are based on following consideration: firstly, internationalization activities should be occurred within three years after firms' foundation. Anderson and Wictor (2003) defined born global firm as "percentage of overseas sales exceed $25 \%$ in the first three years after company's foundation." Above all three firms actively enter international markets within three years after their foundation, they just skip and accelerate traditional internationalization development path which evolves according to "local markets-regional market-national market-international markets." Second issue is about company's internationalization mode, although Andersson, etc. applies quantitative criteria, their definition doesn't take entry mode into consideration, we argue that a firm can not be regarded as truly international company if it relies on export as only overseas market entry mode although its overseas sales take high proportion among whole sales revenues. The case companies the paper has selected all undertake a higher level of entry modes such as cross-border merger and acquisition, establishing wholly owned subsidiaries in foreign markets besides export. Through applying higher commitment of entry modes, those companies seek location advantages and acquire efficiencies from business operating worldwide. The third issue is that those companies realize their fast growth thanks to internationalization activities. Theories on born global firms need to not only answer the question of how newly established firms go global but also to explore how newly established firms expand into overseas markets under complicated international business environment. 


\section{Case study one: Company A}

Company A was established in 1993 in Tsingtao city, Shandong province of China; the company developed its patent glass product in 1994, and it expanded into American market very rapidly in 1995. During company's 20 years development history, its overseas markets expanded very quickly, its products and brand are recognized by a large number of foreign customers. In 2005, company's total sales revenue reached about RMB 1600 million, among them, $95 \%$ of sales revenue come from the overseas market. The company's products are widely sold and distributed among world's 110 countries and districts, directly serve more than 1500 clients globally. Especially in European and American markets, one in four families use company's products, after the success of overseas markets expansion, Company turns back to develop domestic markets, which immeasurably contrast with traditional firms' internationalization process.

The founder of Company A recognized the invaluable business opportunity of candle consumption which is prevalent due to western cultural influence when he studied in the United States. According to statistics, glass products like glass candleholder yield not less than $\$ 3000$ million volume of trade globally. Company A's founder believed that glass products are the last industrial factors China lacks, the company would realize its supernormal development based on glass products. By recognizing and exploiting that business opportunity, company rapidly develop in very short period, till now, company has established business alliances with lots of Fortune 500 companies such as Wal-Mart, Metro, Carrefour, etc. At the same time, Company further its go-global strategy to meet local customers' needs through localized R\&D, design, production, and sales. To avoid international trade and technological barriers, Company has set up its subsidiaries, R\&D centers, outbound processing plants in many countries of Europe, North America, and Southeast Asia. By that way, Company A's R\&D, manufacturing and sales activities are effectively integrated into the global value chain.

\section{Case study two: Company B}

Company B was founded in 2001 by Dr. Zhengrong Shi who has been committed to photovoltaic industry for a long time, In 1999, He got his Ph.D. Degree in photovoltaic products research in Australia, then he chose to return China to set up his own company in 2001, thanks to his Ph.D. supervisor's reputation in the field, company B entered German markets in 2002, then the company gradually expanded its business into other countries in Western European countries. Due to European countries environmental protection bill's compulsory implementation, solar energy photovoltaic industry gradually develops into a seller's market, which makes supplying of company products' is not adequate for the market demand. Under that environment, Company B further strengthen its international marketing networks, the company formulates its marketing strategy of extending to other countries in Europe, Australia, United States and Asia Southeastern countries through centering on the German market. Company B has become a recognizable brand in the international photovoltaic industry, according to international authoritative photovoltaic industry magazine Photon international's statistics, the solar energy cell production capabilities of company B was ranked No. 8 in 2005 and Top 3 in 2006.

On $14^{\text {th }}$ Dec 2005, company B was listed in American New York Stock Exchange, which made the company the first non-state-owned high technology firm which was listed in New York Stock Exchange. Till 2007, the NYSE value of company B reached $\$ 5000$ million, which was the highest among Chinese private firms, while $\mathrm{Dr}$. Zhengrong Shi's personal wealth also reached $\$ 2340$ million. Transforming from an unknown overseas scientist to one of richest guys in China, Zhengrong Shi only takes six years, which become the most rapidly growth case among China's entrepreneurial histories.

\section{Case study three: Company C}

Company C was founded by several returned Chinese Silicon Valley scientists in 1999 under the proposition and support from national information industry ministry, the company headquartered in Beijing Zhongguan Village which aspires to become China's Silicon Valley. Contrast to traditional company's domestic market-overseas market internationalization path, company targets overseas market at the beginning of its foundation. In 2000, company C set up a subsidiary in American Silicon Valley, in 2002, company C set up a subsidiary in Hong Kong to strengthen its overseas marketing efforts.

Company $\mathrm{C}$ has dedicated to developing advanced digital multi-media technology, going through two years painstaking efforts; the company launched its Chips with whole independent intellectual property rights in international markets in Sep. 2001, which demonstrated that a private company only took two years to expand into intensely competitive international markets, its internationalization pace has surprised lots of its competitors. Company's chips are widely adopted by international reputable electronics companies such as Samsung, Philips, and HP, etc. It occupies about $60 \%$ market share in computer image input chips at the moment. 


\subsection{Cross case studies analysis}

\subsubsection{International entrepreneurship opportunity is recognition and exploitation}

According to different entrepreneurial motives, entrepreneurial activities can be divided into opportunity-pull and poverty-push entrepreneurial activities. Under Opportunity-pull perspective, entrepreneurs are mainly attracted by markets opportunities in contrast to compelling due to poverty in poverty-push perspective. As a new entrepreneurial mode of globalization epoch, born global firms' foundation and growth are featured with distinct opportunity-pull entrepreneurial activities characteristics, they focus more on utilizing various resources to exploit unknown business opportunities rather than compelled by poverty. In above three case studies, all founders of Company A, Company B and Company C and the founding team have a higher level of education, they all had enviable jobs before setting up their own business, why did they give up those stable and enviable job and choose to set up their company with risks? The main reason is that they all have discovered and recognized business opportunities from international markets.

When Company A's founder studied in the United States, he just noticed that candle related glass products have great business potential in Western countries, while all production factors related to glass products are prevalent and inexpensive in China, by connecting inexpensive China's manufacturing capabilities with customized R\&D and marketing capabilities in western countries, company succeed in achieving rapid international expansion in just very short time.

In Company B's case, due to the cost of photovoltaic electricity generating system is much higher than market's mainstream electricity generating system, so its market expansion is closely related to host countries' government policies, since the year 2003, European countries had forcefully implemented environmental protection bills, which made low carbon solar energy an ideal government supported electricity generating alternative, by that reason, company B ushered in a rare opportunity, and the solar energy photovoltaic industry gradually evolved into a seller's market.

In Company C's case, the company is proactively involved in the cutting edge technological transferring trend from western developed countries to Asian countries especially China, which endows Chinese domestic high-tech companies invaluable opportunity to develop their innovative core technology and commercialize those technologies. Although western countries are advantageous in leading technologies and mature fund raising system, China is also endowed with growing market economic environment, large increasing domestic demand, comparatively lower cost of human capital and innovative technologies which are greatly valued and supported by Chinese government, all of which provide domestic firms with fantastic development opportunity and environment.

\subsubsection{Global resources and knowledge is integration}

To newly established ventures with very constrained resources, the crucial question of internationalization activities not lie in how to fully elaborate and exploit their extant resources and capabilities, but how to acquire, accumulate external resources from external environment for further growth with a better, faster, and more effective approach. In the foundation and development process of Company A, not only domestic industrial resources and low-cost production capabilities were fully exploited, but external networking opportunities such as distribution channels of international giant supermarkets such as Wal-Mart, Carrefour are leveraged. In Company B's case, its founder utilized every network resource in the solar photovoltaic industry he was able to access at the beginning of firm's foundation. To enter developed countries market, company B's founder asked his Ph.D. supervisor Martin Green to help him in product introduction, his colleagues in Australia Pacific solar energy research center were invited to do market research. In start-up capital aspect, the company was also substantially supported by China's local municipal government's state-owned enterprises funds. In target market aspect, company B was fundamentally European markets orientated. Thus, company B's entrepreneurial path and resource integration approach can be summed up into "Overseas returnee + Overseas advanced technology + International markets + Listed in Overseas stock exchange" mode. At the beginning of Company C's start-up, it established subsidiaries in American Silicon Valley and Austin, the purpose was not only to obtain latest scientific breakthrough information but also demonstrate and distribute company C's cutting edge technological products. Developed technologies, expertise, mature business management and venture capital running industrial factors are widely existed in Silicon Valley, while large markets with great potential, numerous clients, and qualified engineers are available in China. By connecting Silicon Valley's high technology, innovative corporate governance with Chinese markets and manufacturing capabilities, company C grows rapidly, and the overseas market could be expanded in an accelerated way. 


\subsubsection{Entrepreneurial team with rich overseas market experiences}

One crucial reason for born global firms to realize their global resources and knowledge integration, successfully recognize and exploit opportunities in overseas market lies in that born global firms are endowed with the entrepreneurial team which has rich overseas market experiences.

The founder of above case companies all once studied or worked in foreign countries. Company A's founder once studied in America and obtained master degree in economics there, he also worked four years in a local American company; Company B's founder once studied in Australian University of New South Wales, and was supervised by "Father of solar energy", 2002 Nobel Environmental Prize winner Professor Martin Green, when he completed his Ph.D. studies in Australia UNSW, he worked as senior manager and Scientist in Australian Pacific solar energy electricity company, Ltd. In Company C's case, the entrepreneurial team was formed up of about 45 overseas returnees, most of them once studied in top universities in western developed countries and worked for reputable companies in Silicon Valley.

Thus, those entrepreneurs with overseas education background, overseas working and living experiences have demonstrated intensified global mindset and internationalization tendency, international experiences and overseas knowledge which they have obtained before setting up their companies enabled them to reduce risks and exploring costs in international markets expansion effectively, and by that reason, those newly established Chinese companies managed to conduct their internationalization activities very shortly after foundation.

\subsubsection{Born global firms are more advantageous than traditional firms in learning}

Comparing with large Multinational Corporation with a long history, newly established firms which are less constrained by routine and traditions are more advantageous in learning especially under new international business environment. Born global firms are much simpler in corporate organization structure, managers and employees from company's different departments have more opportunities to communicate and discuss with each other, and those intimate interactions would enable tacit knowledge to be shared throughout the company. The reason why Company $\mathrm{C}$ manage to realize series of technological heavy weight innovation and breakthrough lies in that the company benefits a lot from knowledge sharing platform which was set up by those entrepreneurial returnees from Silicon Valley, most of them had rich work experiences in computer chips design when they worked for international famous IT companies in Silicon Valley, they didn't take their experiences and knowledge as top secrets which must be kept carefully but are willing to communicate with each other and encourage employees to learn from the sharing knowledge. Company founder and technological gurus do scientific experiments with employees, they just transfer their cutting edge technologies to those employees who have just graduated from universities in a generous way, that mentoring knowledge sharing method enabled lots of employees who have just graduated from universities to get access to world's most advanced technologies.

Company $\mathrm{C}$ also encourages its employees to learn related technologies in other departments apart from their departments, to undertake more challenging technological projects. That mentoring organization learning platform promotes company $\mathrm{C}$ to cultivate a technological research and development team which can compete with foreign computer chip design giants; the company combines every excellent resource it can access to produce world's leading technologies and products.

\subsection{Conclusion}

As a new form of internationalized companies, one fundamental question must be asked is that how born global firms are set up. A further question follows is that how those born global firms realize their fast development when they are not endowed with resources advantages and competencies that are widely available in mature multinational corporations? Through above Chinese-born global companies case studies analysis, we found that International entrepreneurship enables Chinese entrepreneurs to perceive and exploit oversea opportunities by taking risks, which become the prerequisite for Chinese born global firms' emergence; international social capital and network relationships serve as intermediaries to make Chinese-born global firms' further growth viable; Chinese-born global firms' ongoing process of internalization also provides firms with newly international knowledge and organizational learning opportunities which are absorbed, assimilated and leveraged by Chinese firms to constitute sustainable competitive advantages. 


\section{References}

Andersson S, Wictor I. (2003). Innovative internationalization in new firms: Born globals-The Swedish case. Journal of International Entrepreneurship, 1 (3), 249-276. http://dx.doi.org/10.1023/A:1024110806241

Autio E. (2005). Creative tension: The significance of Ben Oviatt and Patricia McDougalls article"toward a theory of international new ventures". Journal of International Business Studies, 36(1), 9-19.

Autio E, Sapienza H J, Almeida J G. (2000). Effects of age at entry, knowledge intensity, and imitability on international growth. Academy of Management Journal, 43(5), 909-924. http://www.jstor.org/stable/1556419

Dimitratosa P, Jonesh M V. (2005). Future directions for international entrepreneurship research. International Business Review, 14 (2), 119-128.

Eisenhardt K. (1989). Building theories from case study research. Academy of Management Review, 14 (4), 532-550. http://dx.doi.org/10.5465/AMR.1989.4308385

Gabrielsson, M. and Pelkonen, T. (2008). Born internationals: Market expansion and business operation mode strategies in the digital media field Journal of International Entrepreneurship, 6(2), 49-71. http://dx.doi.org/10.1007/s10843-008-0020-z

Harveston P D, Kedia B L, Davis P S. (2000). Internationalization of born global and gradual globalizing firms: The impact of the manager. Advances in Competitiveness Research, 8 (1), 92-99.

Johanson, J., \& Vahlne, J.-E. (1977). the internationalization process of the firm: A model of knowledge development and increasing foreign market commitments. Journal of International Business Studies, 8(1), 23-32. http://dx.doi.org/10.1057/palgrave.jibs. 8490676

Knight G A, Cavusgil S T. (2004). Innovation, organizational capabilities, and the born global firm. Journal of International Business Studies, (35), 124-141. http://dx.doi.org/10.1057/palgrave.jibs.8400071

Knight G G, Cavusgil S T. (1996). The born global firm: A challenge to traditional internationalization theory. Advances in International Marketing, 8 (1), 11-26.

Kuemmerle W. (1997). Building effective R\&D capabilities abroad. Harvard Business Review, 75 (Mar/Apr), $61-70$.

Madsen T K, Servais P., (1997). The internationalization of born globals: An evolutionary process? International Business Review, 6 (6), 561-583. http://dx.doi.org/10.1016/S0969-593(97)00032-2

McDougall P P, Oviatt B M. (2000). International entrepreneurship: The intersection of two research paths. Academy of Management Journal, 43(5), 902-908. http://dx.doi.org/10.2307/1556418

Oviatt B M, McDougall P P. (1994). Toward a theory of international new ventures. Journal of International Business Studies, 25 (1), 45-64. http://dx.doi.org/10.1057/palgrave.jibs.8490193

Oviatt B M, McDougall P P. (1995). Global start-ups: Entrepreneurs on a worldwide stage. Academy of Management Executive, 9 (2), 30-44. http://www.jstor.org/stable/4165256

Stevenson H H, Jarillo C J., (1990). A paradigm of entrepreneurship: Entrepreneurial management. Strategic Management Journal, 11 (5), 17-27. http://dx.doi.org/10.1007/978-3-540-48543-8_7

Weerawardena J, Sullivan GM, Liesch PW, et al. (2007). Conceptualizing accelerated internationalization in the born global firm: A dynamic capabilities perspective. Journal of World Business, 42 (3), 294-306. http://dx.doi.org/10.1016/j.jwb.2007.04.004

Yamakawa Y, Peng MW, Deeds D L. (2008). What drives new ventures to internationalize from emerging to developed economies? Entrepreneurship Theory and Practice, 32 (1), 59-82. http://dx.doi.org/10.1111/j.1540-6520.2007.00216.x

Zahra S A, Ireland R D, Hitt M A. (2000). International expansion by new venture firms: International diversity, mode of market entry, technological learning, and performance. Academy of Management Journal, 43 (5), 925-950. http://dx.doi.org/doi: 10.2307/1556420 